Supporting Information for

\title{
Identifying the Active Site on Graphene Oxide Nanosheets for Ambient Electrocatalytic Nitrogen Reduction
}

Sini Wang, ${ }^{+}$Jingjing Zhu, ${ }^{+}$Yicheng Zhang, ${ }^{+}$Qiangchun Liu, ${ }^{\dagger}$ Guilin $\mathrm{Chen}^{*}{ }^{\circledR}$ and Xiangkai Kong ${ }^{*},+\neq$

${ }^{\dagger}$ Key Laboratory of Green and Precise Synthetic Chemistry and Application, Ministry of Education \& Anhui Province Key Laboratory of Pollutant Sensitive Materials and Environmental Remediation, Huaibei Normal University, Huaibei, Anhui 235000, P. R. China.

${ }^{\ddagger}$ Key Laboratory of Structure and Functional Regulation of Hybrid Materials (Anhui University), Ministry of Education, Hefei, 230601.

${ }^{\S}$ College of Physics and Energy, Fujian Normal University, Fuzhou, Fujian 350007, P. R. China. 


\section{Experimental Section}

Materials: Hydrazine hydrate $\left(\mathrm{N}_{2} \mathrm{H}_{4} \cdot \mathrm{H}_{2} \mathrm{O}\right)$, hydrochloric acid $(\mathrm{HCl})$, sulfuric acid $\left(\mathrm{H}_{2} \mathrm{SO}_{4}\right)$, sodium hypochlorite solution $(\mathrm{NaClO})$, sodium hydroxide $(\mathrm{NaOH})$, ammonium chloride $\left(\mathrm{NH}_{4} \mathrm{Cl}\right)$, and potassium chloride $(\mathrm{KCl})$ were purchased from Sinopharm Chemical Reagent Co. Ltd. Sodium sulfate $\left(\mathrm{Na}_{2} \mathrm{SO}_{4}\right)$, sodium salicylate $\left(\mathrm{C}_{7} \mathrm{H}_{5} \mathrm{NaO}_{3}\right)$, sodium nitroferricyanide dihydrate $\left(\mathrm{C}_{5} \mathrm{FeN}_{6} \mathrm{Na}_{2} \mathrm{O} \cdot 2 \mathrm{H}_{2} \mathrm{O}\right)$, p-dimethylaminobenzaldehyde $\left(\mathrm{C}_{9} \mathrm{H}_{11} \mathrm{NO}\right)$, were purchased from Aladdin Ltd. Nafion solution (5 wt\%) was bought from Dupond company. Carbon papers (TGP-H-060) were purchased from Suzhou yilongsheng Energy Technology Co., Ltd. High-purity $\mathrm{N}_{2}$ (99.999\%) and $\operatorname{Ar}(99.999 \%)$ were purchased from Nanjing Tianze Gas Co. Ltd. GO slurry was obtained from Ashine Advanced Carbon Material Co. Ltd.

Working electrode preparation: $0.25 \mathrm{~mL}$ graphene oxide (GO) slurry was mixed with $2 \mathrm{~mL}$ ethanol and then $20 \mathrm{uL}$ Nafion solution was added in. The mixture was under sonication for $1 \mathrm{~h}$ to from a homogeneous dispersion. A piece of carbon paper $(\mathrm{CP}, 3 \mathrm{~cm} \times 3 \mathrm{~cm})$ was ultrasonic cleaned in ethanol for $30 \mathrm{~min}$, then washed for several times with deionized water. Afterwards, the GO dispersion was dropped onto CP surface using spinning coating method. The GO loaded CP was cut into pieces of $0.5 \mathrm{~cm} \times 0.5 \mathrm{~cm}$ in size. The loading mass of GO is estimated to be $0.45 \mathrm{mg} \mathrm{cm}^{-2}$. Different potentials of $-0.2,-0.4$ and $-0.6 \mathrm{~V}$ were applied for $100 \mathrm{~s}$ in the $0.1 \mathrm{M} \mathrm{Na}_{2} \mathrm{SO}_{4}$ solution, which were denoted as ERGO-0.2, ERGO-0.4 and ERGO-0.6, respectively, and used as the working electrodes for the future NRR measurements.

Electrochemical Measurements: Electrochemical measurements were implement on a CHI-760E electrochemical workstation with an H-type electrolytic cell separated by a Nafion membrane. A standard three-electrode system was used in all measurement, including the ERGO materials, a graphite rod and a $\mathrm{Ag} / \mathrm{AgCl}$ electrode as the working electrode, counter electrode and reference electrode, respectively. All potentials were converted into the reversible hydrogen electrode as following: $\mathrm{E}(\mathrm{RHE})=\mathrm{E}(\mathrm{Ag} / \mathrm{AgCl})+0.059 \times \mathrm{pH}+0.197 \mathrm{~V}$. All tests are performed at room temperature. The electrolyte in this test is $0.1 \mathrm{M} \mathrm{Na}_{2} \mathrm{SO}_{4}$ with the amount of $40 \mathrm{~mL}$. The $\mathrm{N}_{2}$ and $\mathrm{Ar}$ gas $(99.999 \%$ purity) were used in this test. The H-type electrolytic cell used in this test were cleaned in dilute sulfuric acid in advance to remove $\mathrm{NH}_{3}$ that could be adsorbed on the surface. Before testing, the electrolyte was purified by purging high purity $\mathrm{N}_{2}$ into the electrolyte for 30 min. During the test, the gas velocity in the cathodic compartment was kept at $20 \mathrm{~mL} \mathrm{~min}^{-1}$, and the electrolyte was stirred at a speed of $600 \mathrm{rpm}$.

Determination of $\mathbf{N H}_{3}$ : The content of $\mathrm{NH}_{3}$ was detected by the UV-vis spectrophotometry with indophenol blue approach. In detail, $4 \mathrm{~mL}$ of electrolyte obtained from the electrochemical reaction vessel was mixed with $50 \mathrm{uL} \mathrm{NaClO}$ containing $0.75 \mathrm{M} \mathrm{NaOH}$ solution. Subsequently, $500 \mathrm{uL}$ of coloring solution containing $0.4 \mathrm{M} \mathrm{C}_{7} \mathrm{H}_{5} \mathrm{NaO}_{3}$ and $0.32 \mathrm{M} \mathrm{NaOH}$, and $50 \mathrm{uL}$ of catalyst reagent $1 \mathrm{wt} \% \mathrm{Na}_{2}\left[\mathrm{Fe}(\mathrm{CN})_{5} \mathrm{NO}\right]$ were added in. After incubating at room temperature in dark for 2 $\mathrm{h}$, the absorbance of the solution was measured at $\lambda=660 \mathrm{~nm}$. The yields of $\mathrm{NH}_{3}$ is quantified by the well-fitted calibration curve of $\left(\mathrm{NH}_{4}\right)_{2} \mathrm{SO}_{4}\left(\mathrm{y}=0.6019 \mathrm{x}+0.00402, \mathrm{R}^{2}=0.999\right)$ and the formation rate was calculated based on the equation as follows:

$\mathrm{NH}_{3}$ yield $=\left[\mathrm{NH}_{4}^{+}\right] \times \mathrm{V} \times 17 /\left(\mathrm{m}_{\text {cat }} \times \mathrm{t} \times 18\right)$

The FE was calculated based on the equation as follow: 
$\mathrm{FE}=3 \times \mathrm{F} \times\left[\mathrm{NH}_{3}\right] \times \mathrm{V} /(17 \times \mathrm{Q})$

Where $\left[\mathrm{NH}_{4}^{+}\right]$is measured $\left(\mathrm{NH}_{4}\right)_{2} \mathrm{SO}_{4}$ concentration, $\mathrm{V}$ is the volume of electrolyte, $\mathrm{t}$ is the reduction reaction time, $\mathrm{m}_{\text {cat }}$ is the loading mass of ERGO catalyst, $\mathrm{F}$ is the Faraday constant, $\mathrm{Q}$ is the quantity of applied electricity, $\left[\mathrm{NH}_{3}\right]$ is the calculated $\mathrm{NH}_{3}$ concentration.

Determination of $\mathbf{N}_{2} \mathrm{H}_{4}$ : The content of $\mathrm{N}_{2} \mathrm{H}_{4}$ was detected by the Watt and Chrisp approach. The color reagent was prepared from the mixture of $\mathrm{C}_{9} \mathrm{H}_{11} \mathrm{NO}(0.599 \mathrm{~g}), \mathrm{HCl}$ (concentrated, $3 \mathrm{~mL}$ ), and $\mathrm{C}_{2} \mathrm{H}_{5} \mathrm{OH}(30 \mathrm{~mL})$. Typically, $2 \mathrm{~mL}$ of electrolyte obtained from the cathodic compartment was add to $2 \mathrm{~mL}$ of the above color reagent. After incubating it at room temperature for $20 \mathrm{~min}$, the absorbance of the solution was measured at $\lambda=455 \mathrm{~nm}$. The absorbance curve was calibrated with a series of concentrations of $\mathrm{N}_{2} \mathrm{H}_{4}$ solution to obtain a fitting linear relationship $(y=0.755 \mathrm{x}+$ $0.01459, \mathrm{R}^{2}=0.999$ ) between the absorbance value and $\mathrm{N}_{2} \mathrm{H}_{4}$ concentration.

${ }^{15} \mathrm{~N}$ isotopic labeling experiment: The ${ }^{15} \mathrm{~N}_{2}$ was used as the feeding gas for the isotopic labeling analysis, at $-0.04 \mathrm{~V}$ (RHE) for $12 \mathrm{~h}$, to certify the $\mathrm{N}_{2}$ origination of ammonia. After reaction, the electrolyte was concentrated, followed by adding DMSO. The produced ammonia was confirmed using ${ }^{1} \mathrm{H}$ nuclear magnetic resonance measurements (BRUKER, Ascend $600 \mathrm{MHz}$ )

DFT calculations: All of the calculations in this study were performed based on the DFT scheme implemented in the Gaussian 16 package. ${ }^{1}$ Full optimization with the B3PW91 functional is employed to obtain the ground-state molecular structures, as it can give more reliable intermolecular interaction energy than other functionals. ${ }^{2}$ There are no imaginary frequencies, ensuring that all of the structures are stable. Polarization functions are supplied by using the 6-31G* basis set for $\mathrm{C}, \mathrm{H}, \mathrm{N}$, and $\mathrm{O}$ atoms. Both the functional and basis set have been used in the previous work, and they are appropriate for the large systems as discussed here. Geometry relaxations are conducted until the gradient forces are smaller than a threshold value of $0.012 \mathrm{eV}$, and the simulations are all performed with a $(75,302)$ pruned grid. 

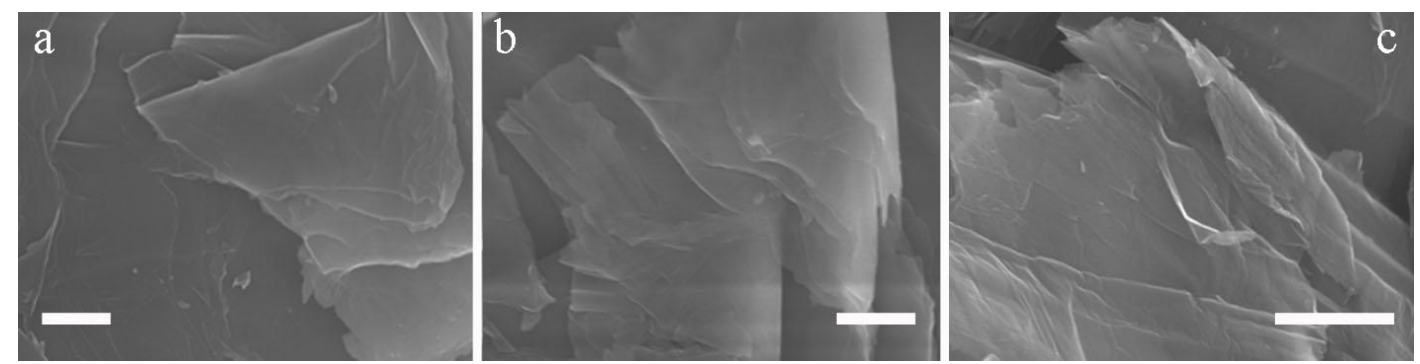

Fig. S1. SEM images of (a) ERGO-0.4, (b) ERGO-0.2 and (c) ERGO-0.6. Scale bar: $1 \mu \mathrm{m}$.
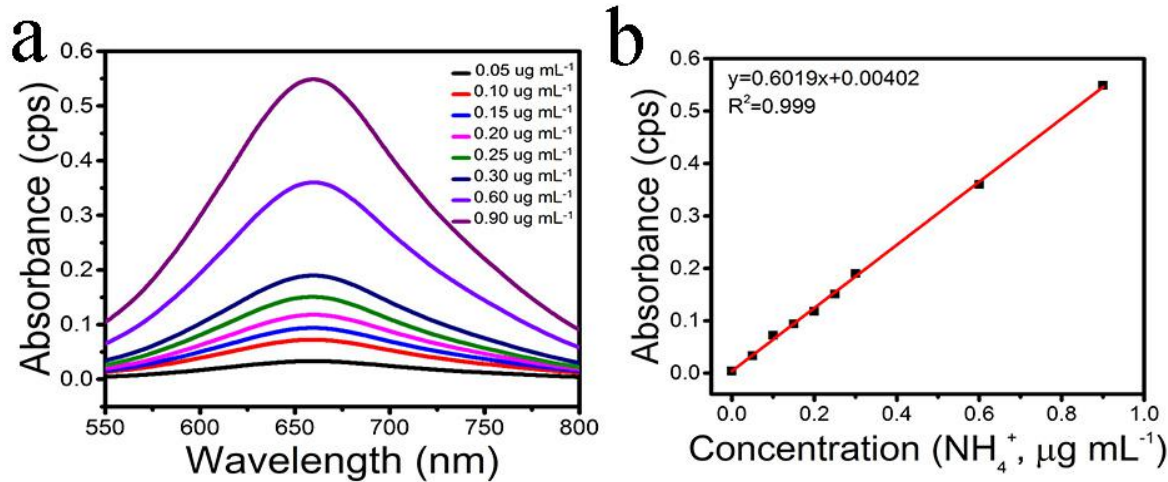

Fig. S2. (a) UV-Vis absorption spectra of various $\mathrm{NH}_{3}$ concentrations after incubated for $2 \mathrm{~h}$ at room temperature. (b) Calibration curve used for estimation of $\mathrm{NH}_{3}$ concentration. 

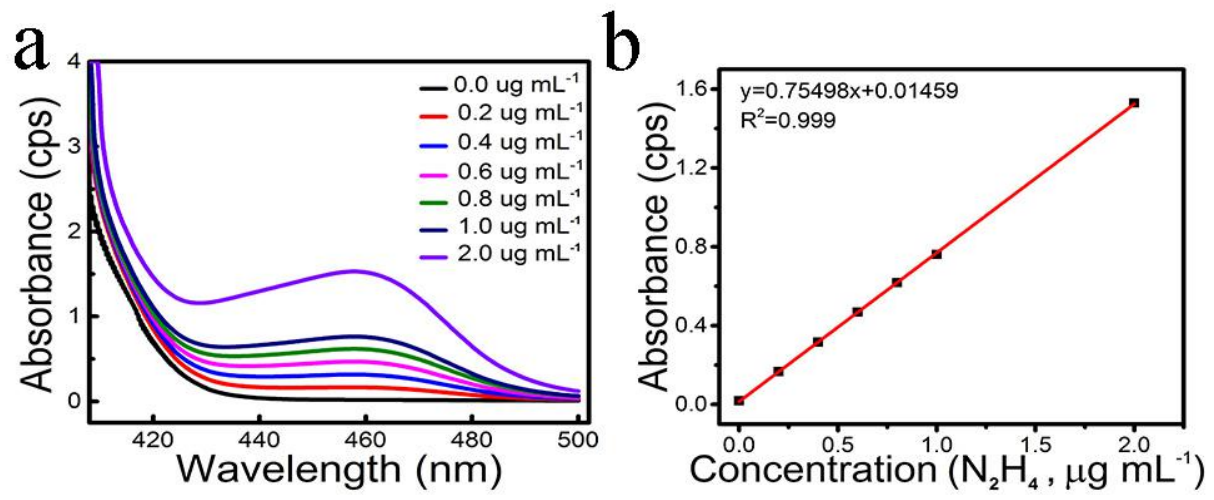

Fig. S3. (a) UV-Vis absorption spectra of various $\mathrm{N}_{2} \mathrm{H}_{4}$ concentrations after incubated for $15 \mathrm{~min}$ at room temperature. (b) Calibration curve used for estimation of $\mathrm{N}_{2} \mathrm{H}_{4}$ concentration.

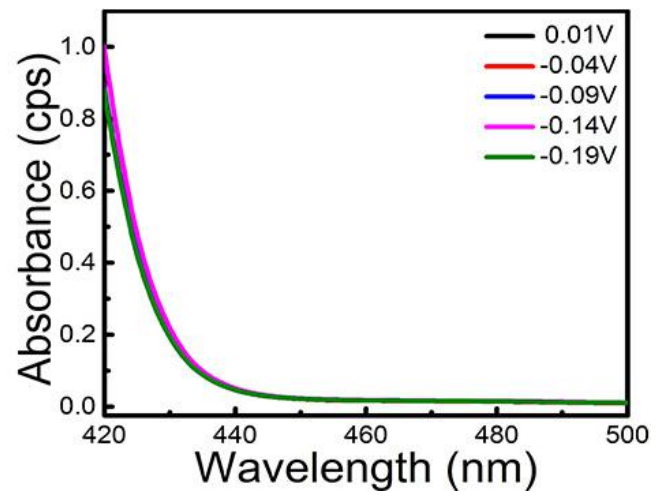

Fig. S4. UV-Vis absorption spectra of the electrolytes stained with $\mathrm{C}_{9} \mathrm{H}_{11} \mathrm{NO}$ indicator after NRR electrolysis at a series of potentials. 


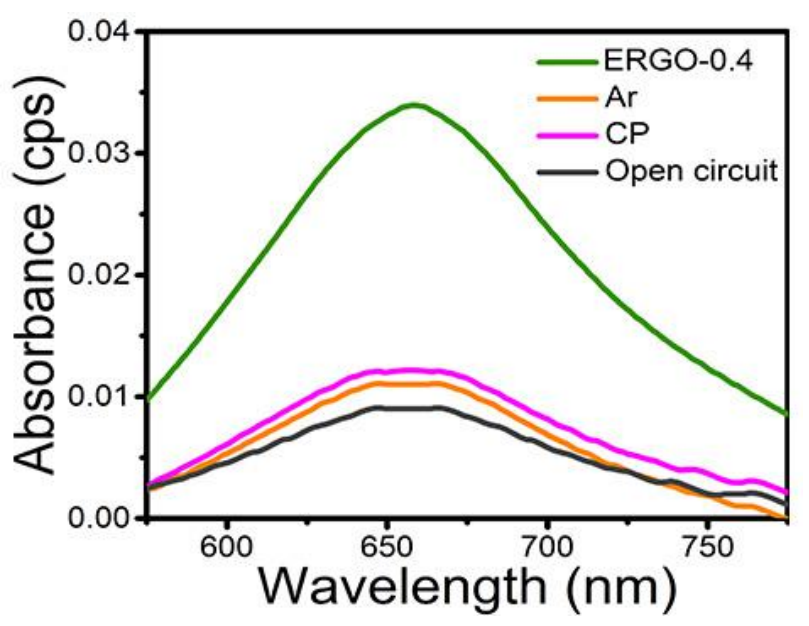

Fig. S5. UV-Vis absorption spectra of the electrolytes stained with indophenol indicator after NRR electrolysis under a series of conditions.

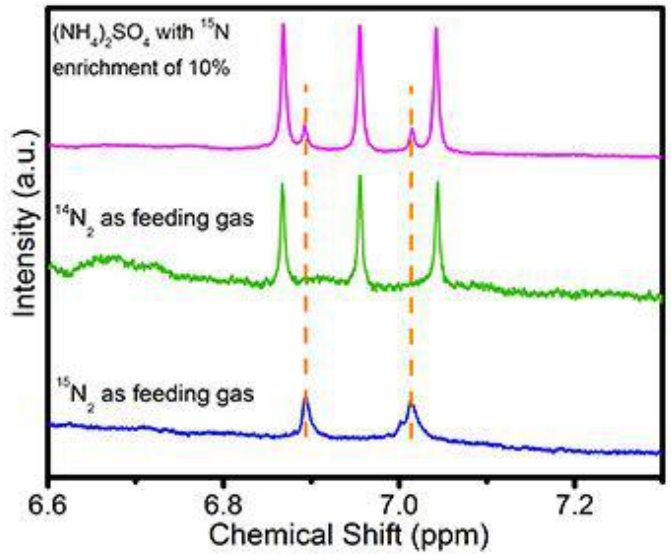

Fig. S6. NMR spectra of the NRR product when using ${ }^{14} \mathrm{~N}_{2}$ (green line) and ${ }^{15} \mathrm{~N}_{2}$ (blue line) as the feeding gas . 


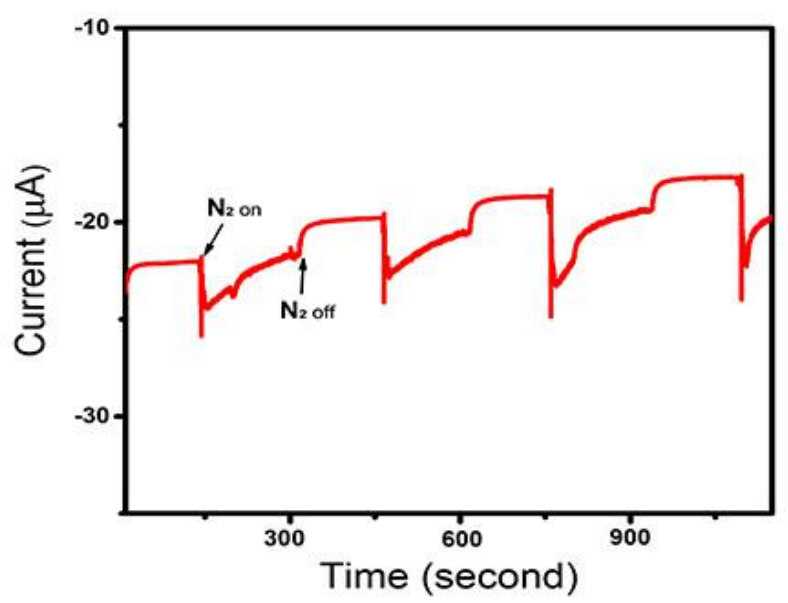

Fig. S7. A static current measurement with intermittent $\mathrm{N}_{2}$ supply on ERGO-0.4.
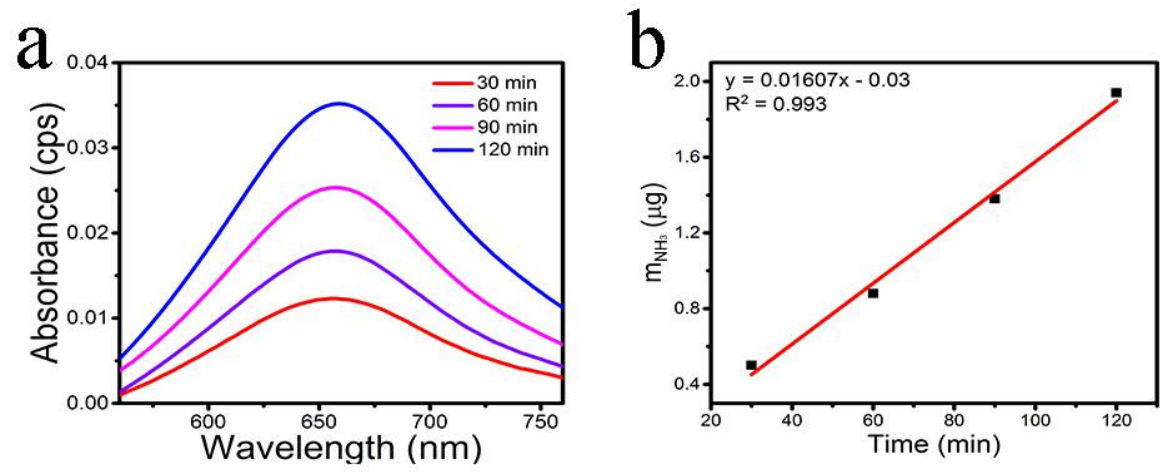

Fig. S8. (a) UV-Vis absorption spectra using indophenol method for ERGO-0.4 at different reaction times. (b) Corresponding measured $\mathrm{NH}_{3}$ amount in the solution against reaction time. 

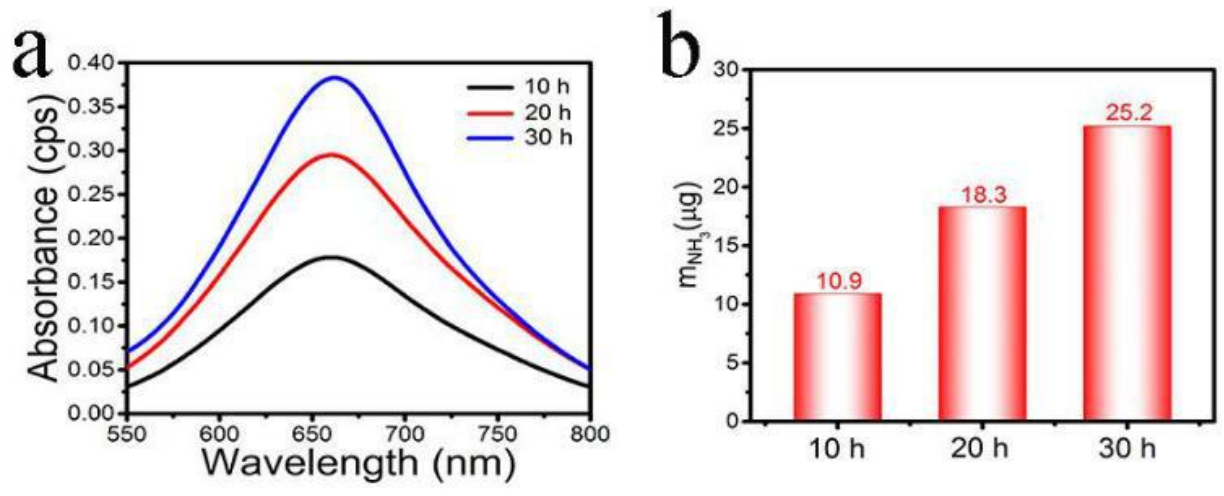

Fig. S9. (a) UV-Vis absorption spectra using indophenol method for ERGO-0.4 at different reaction times for long-term electrolysis. (b) Corresponding measured $\mathrm{NH}_{3}$ amount in the solution against reaction time.

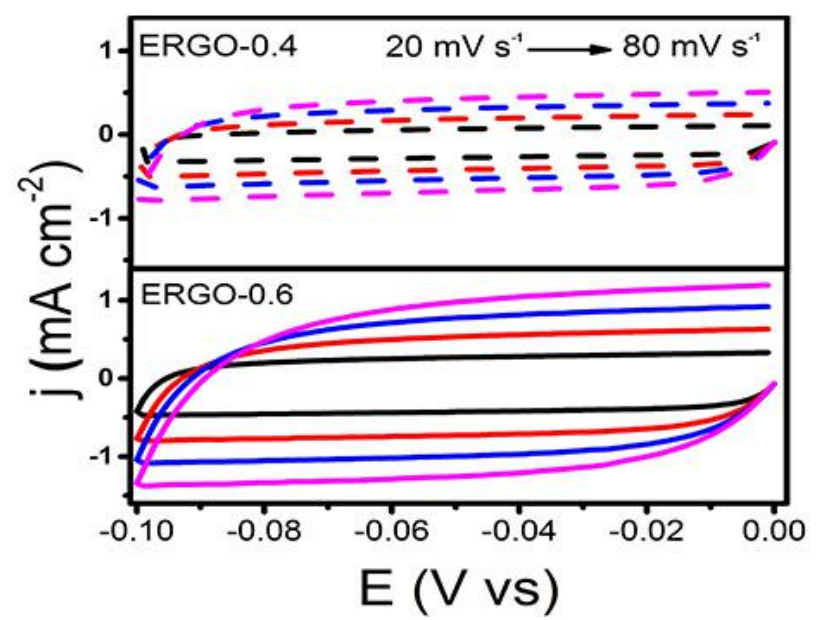

Fig. S10. The double layer capacitance measurements on ERGO-0.4 and ERGO-0.6, with the CV curves running at different scanning rates. 

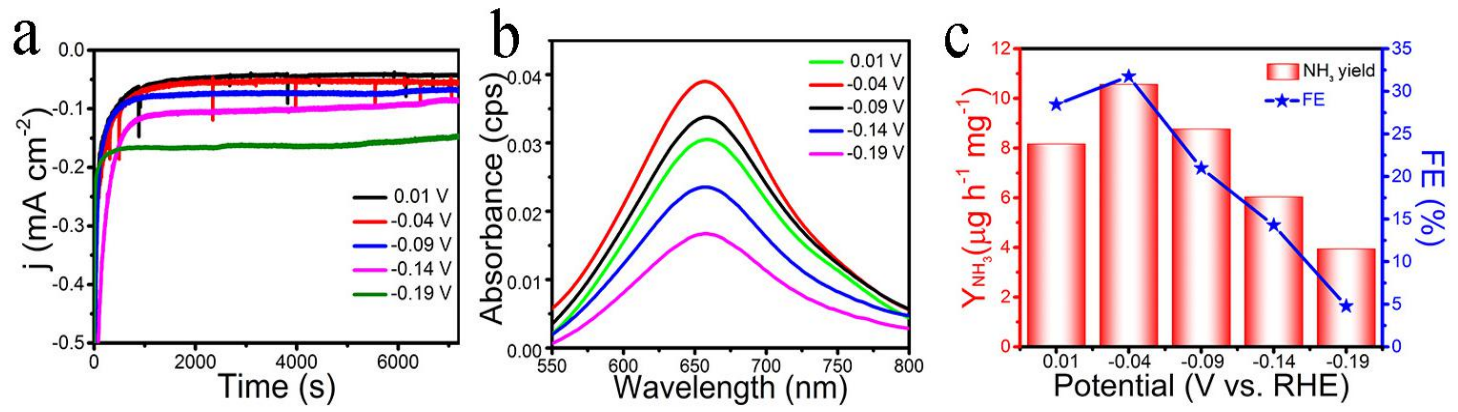

Fig. S11. The NRR performance on ERGO-0.2. (a) Time-dependent current density curves at different potentials. (b) UV-vis spectra with indophenol indicator after NRR reaction at different potentials. (d) Yield of $\mathrm{NH}_{3}$ and corresponding FEs.
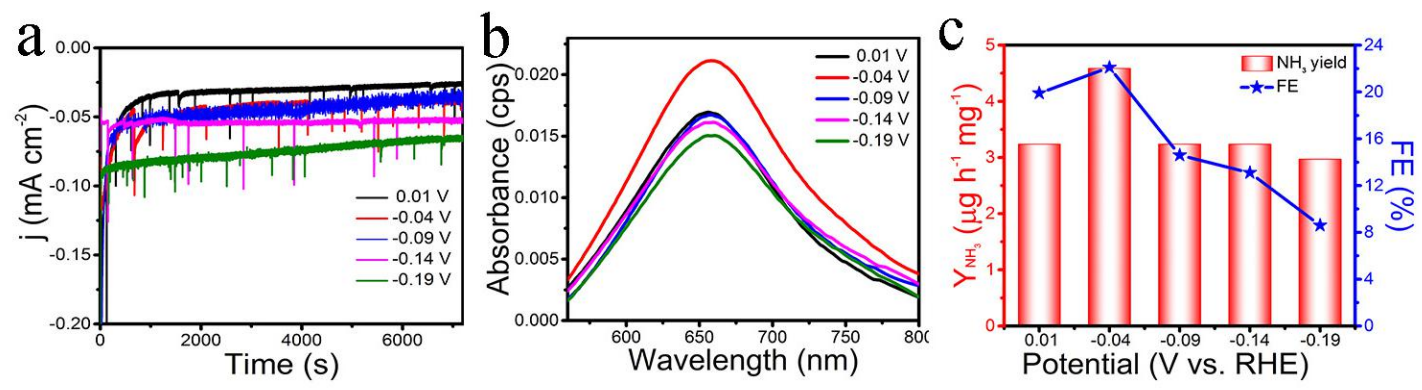

Fig. S12. The NRR performance on ERGO-0.6. (a) Time-dependent current density curves at different potentials. (b) UV-vis spectra with indophenol indicator after NRR reaction at different potentials. (d) Yield of $\mathrm{NH}_{3}$ and corresponding FEs. 


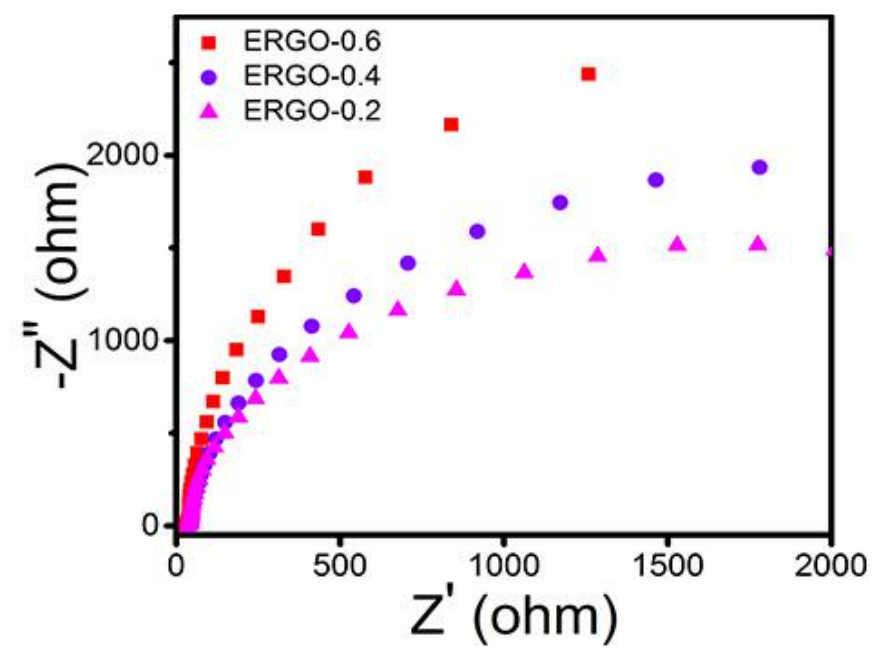

Fig. S13. The EIS data measured at $-0.04 \mathrm{~V}$ on ERGO-0.2, ERGO-0.4 and ERGO-0.6.
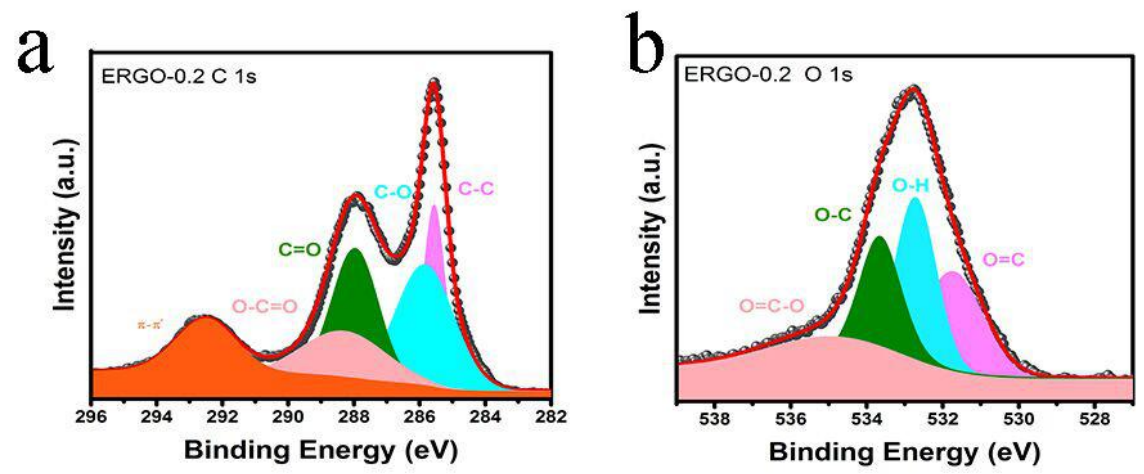

Fig. S14. XPS spectra of ERGO-0.2 for (a) C 1s and (b) O 1s signals. 

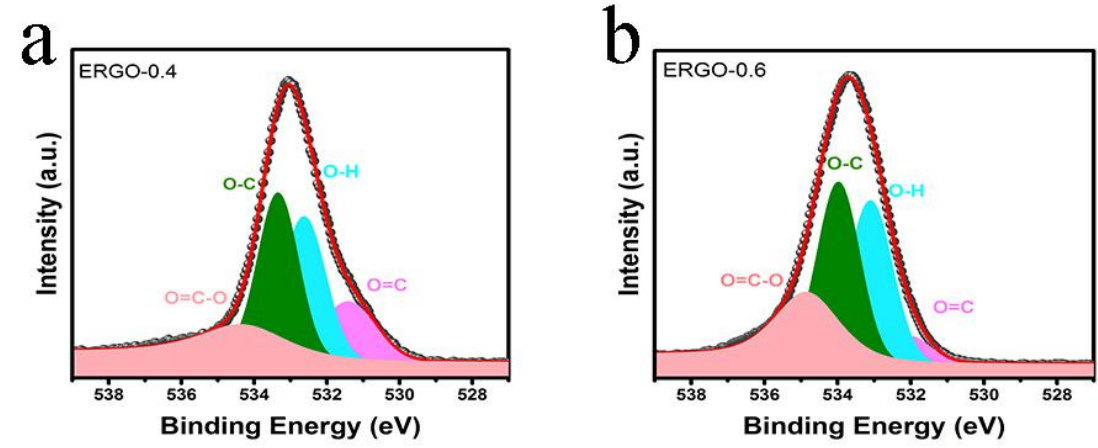

Fig. S15. XPS spectra of O 1s for (a) ERGO-0.4 and (b) ERGO-0.6.

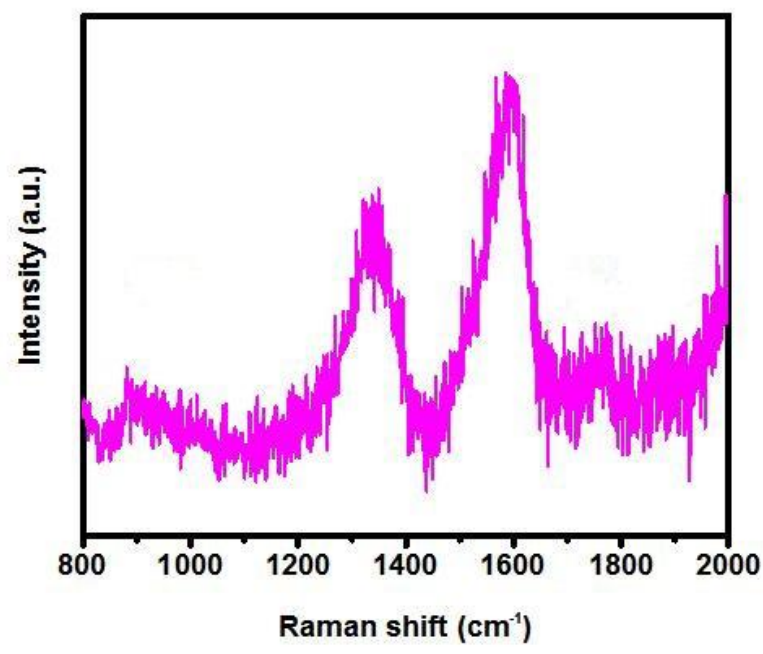

Fig. S16. Raman spectrum measured on pure GO nanosheets. 


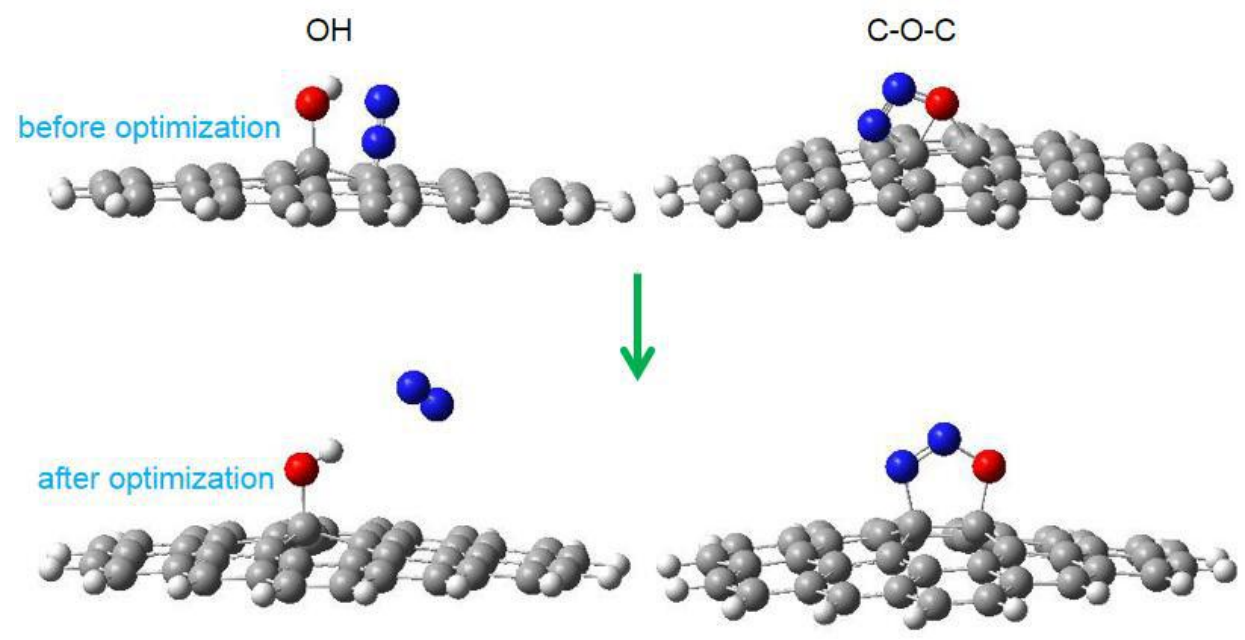

Fig. S17. The models for $\mathrm{N}_{2}$ combined with $\mathrm{OH}$ and $\mathrm{C}-\mathrm{O}-\mathrm{C}$ groups decorated graphene catalysts. The up and bottom figures are corresponding structures before optimization and after optimization.

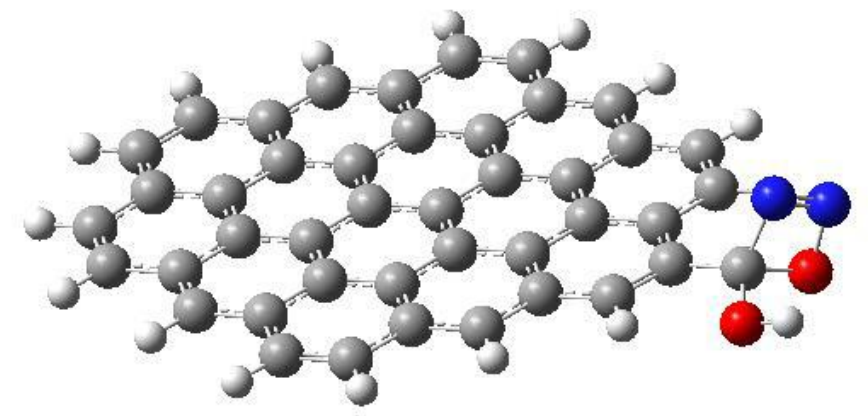

Fig. S18. The optimized structure for $\mathrm{N}_{2}$ adsorbed on $\mathrm{COOH}$ decorated graphene catalyst. The bond length for $\mathrm{N}-\mathrm{N}$ and $\mathrm{C}-\mathrm{O}$ bonds are 1.25 and 1.49 angstrom, respectively. 


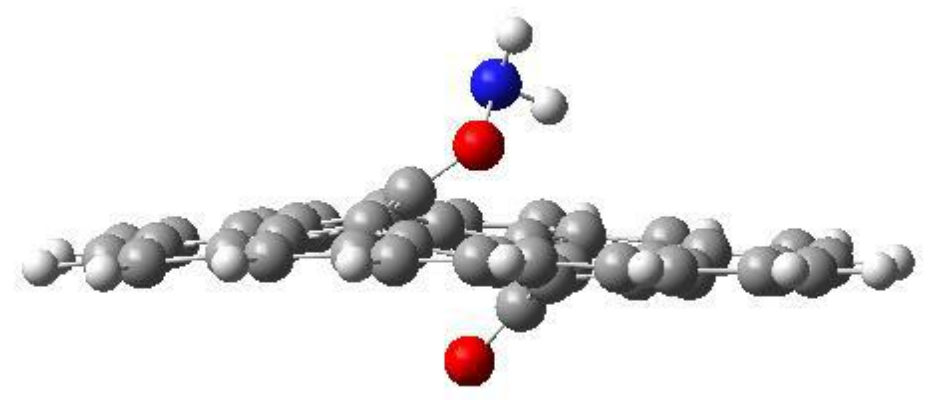

Fig. S19. The optimized structure for $\mathrm{NH}_{2}$ intermediate adsorbed on $\mathrm{C}=\mathrm{O}$ decorated graphene catalyst. 
Table S1. The comparisons of the NRR activity of ERGO-0.4 with recently reported catalysts under ambient conditions.

\begin{tabular}{|c|c|c|c|c|c|c|}
\hline Catalyst & Electrolyte & $\mathrm{NH}_{3}$ Yield Rate & $\begin{array}{l}\text { FE } \\
(\%)\end{array}$ & $\begin{array}{l}\text { Potential } \\
\text { (vs RHE) }\end{array}$ & $\begin{array}{c}\text { Current } \\
\text { Density } \\
\left(\mathrm{mA} \mathrm{cm}^{-2}\right)\end{array}$ & Ref. \\
\hline ERGO-0.4 & $\begin{array}{c}0.1 \mathrm{M} \\
\mathrm{Na}_{2} \mathrm{SO}_{4}\end{array}$ & $9.91 \mu \mathrm{g} \mathrm{h}^{-1} \mathrm{mg}^{-1}$ & 38.1 & $-0.04 \mathrm{~V}$ & -0.052 & $\begin{array}{l}\text { This } \\
\text { work }\end{array}$ \\
\hline Mo nanofilm & $\begin{array}{l}0.01 \mathrm{M} \\
\mathrm{H}_{2} \mathrm{SO}_{4}\end{array}$ & $18.9 \mu \mathrm{g} \mathrm{h}^{-1} \mathrm{~cm}^{-2}$ & 0.72 & $-0.49 \mathrm{~V}$ & $\sim 0.0089$ & (3) \\
\hline $\mathrm{BiVO}_{4}$ & $\begin{array}{c}0.2 \mathrm{M} \\
\mathrm{Na}_{2} \mathrm{SO}_{4}\end{array}$ & $8.60 \mu \mathrm{g} \mathrm{h}^{-1} \mathrm{mg}^{-1}$ & 10.04 & $-0.50 \mathrm{~V}$ & $\sim-0.15$ & (4) \\
\hline $\mathrm{Pd} / \mathrm{C}$ & $\begin{array}{c}0.1 \mathrm{M} \\
\mathrm{Na}_{2} \mathrm{SO}_{4} \\
\end{array}$ & $4.5 \mu \mathrm{g} \mathrm{h}^{-1} \mathrm{mg}_{\mathrm{pd}}{ }^{-1}$ & 8.2 & $0.10 \mathrm{~V}$ & $\sim-8.0$ & $(5)$ \\
\hline $\mathrm{MoS}_{2}$ & $\begin{array}{c}0.1 \mathrm{M} \\
\mathrm{Na}_{2} \mathrm{SO}_{4}\end{array}$ & $4.94 \mu \mathrm{g} \mathrm{h}^{-1} \mathrm{~cm}^{-2}$ & 1.17 & $-0.50 \mathrm{~V}$ & $\sim-2.6$ & (6) \\
\hline AuHNCs-715 & $\begin{array}{c}0.5 \mathrm{M} \\
\mathrm{LiClO}_{4}\end{array}$ & $3.74 \mu \mathrm{g} \mathrm{cm}^{-2} \mathrm{~h}^{-1}$ & 35.9 & $-0.40 \mathrm{~V}$ & $\sim-0.05$ & (7) \\
\hline $\mathrm{NbO}_{2}$ & $\begin{array}{l}0.05 \mathrm{M} \\
\mathrm{H}_{2} \mathrm{SO}_{4}\end{array}$ & $11.6 \mu \mathrm{g} \mathrm{h}^{-1} \mathrm{mg}^{-1}$ & 32 & $-0.65 \mathrm{~V}$ & $\sim-0.25$ & (8) \\
\hline $\mathrm{PdAu} / \mathrm{NF}$ & $\begin{array}{c}0.1 \mathrm{M} \\
\mathrm{Na}_{2} \mathrm{SO}_{4} \\
\end{array}$ & $9.42 \mu \mathrm{g} \mathrm{h}^{-1} \mathrm{~cm}^{-2}$ & 13.36 & $-0.20 \mathrm{~V}$ & $\sim-0.25$ & (9) \\
\hline Au NRs & $0.1 \mathrm{M} \mathrm{KOH}$ & $1.65 \mu \mathrm{g} \mathrm{h}^{-1} \mathrm{~cm}^{-2}$ & 4.02 & $-0.20 \mathrm{~V}$ & $\sim-0.22$ & (10) \\
\hline $\mathrm{a}-\mathrm{Au} / \mathrm{CeOx}-\mathrm{RGO}$ & $0.1 \mathrm{M} \mathrm{HCl}$ & $8.3 \mu \mathrm{g} \mathrm{h}^{-1} \mathrm{mg}^{-1}$ cat & 10.1 & $-0.20 \mathrm{~V}$ & $\sim-0.08$ & (11) \\
\hline $\mathrm{Pd}_{0.2} \mathrm{Cu}_{0.8} / \mathrm{rGO}$ & $0.1 \mathrm{M} \mathrm{KOH}$ & $2.8 \mu \mathrm{g} \mathrm{h}^{-1} \mathrm{mg}^{-1}$ cat & $\sim 0.6$ & $-0.20 \mathrm{~V}$ & $\sim-0.85$ & (12) \\
\hline $\mathrm{PEBCDa} / \mathrm{C}$ & $\begin{array}{c}0.5 \mathrm{M} \\
\mathrm{Li}_{2} \mathrm{SO}_{4} \\
\end{array}$ & $1.58 \mu \mathrm{g} \mathrm{h}^{-1} \mathrm{~cm}^{-2}$ & 2.85 & $-0.50 \mathrm{~V}$ & - & (13) \\
\hline $\mathrm{Au} \mathrm{HNCs}$ & $\begin{array}{l}0.5 \mathrm{mM} \\
\mathrm{LiClO}_{4} \\
\end{array}$ & $3.90 \mu \mathrm{g} \mathrm{h}^{-1} \mathrm{~cm}^{-2}$ & 30.2 & $-0.50 \mathrm{~V}$ & $\sim-0.12$ & (14) \\
\hline $\mathrm{Fe}_{3} \mathrm{O}_{4} / \mathrm{Ti}$ & $\begin{array}{c}0.1 \mathrm{M} \\
\mathrm{NaSO}_{4}\end{array}$ & $3.43 \mu \mathrm{g} \mathrm{h}^{-1} \mathrm{~cm}^{-2}$ & 2.6 & $-0.40 \mathrm{~V}$ & $\sim-1.1$ & (15) \\
\hline
\end{tabular}

\section{Reference}

(1) Frisch, M. J.; Trucks, G. W.; Schlegel, H. B.; Scuseria, G. E.; Robb, M. A.; Cheeseman, J. R.; Scalmani, G.; Barone, V.; Petersson, G. A.; Nakatsuji, H.; Li, X.; Caricato, M.; Marenich, A. V.; Bloino, J.; Janesko, B. G.; Gomperts, R.; Mennucci, B.; Hratchian, H. P.; Ortiz, J. V.; Izmaylov, A. F.; Sonnenberg, J. L.; D., Williams-Young; Ding, F.; Lipparini, F.; Egidi, F.; Goings, J.; Peng, B.; Petrone, A.; Henderson, T.; Ranasinghe, D.; Zakrzewski, V. G.; Gao, J.; Rega, N.; Zheng, G.; Liang, W.; Hada, M.; Ehara, M.; Toyota, K.; Fukuda, R.; Hasegawa, J.; Ishida, M.; Nakajima, T.; Honda, Y.; Kitao, O.; Nakai, H.; Vreven, T.; Throssell, K.; Montgomery, J. A., Jr.; Peralta, J. E.; Ogliaro, F.; Bearpark, M. J.; Heyd, J. J.; Brothers, E. N.; Kudin, K. N.; Staroverov, V. N.; Keith, T. A.; Kobayashi, R.; Normand, J.; Raghavachari, K.; Rendell, A. P.; Burant, J. C.; Iyengar, S. S.; Tomasi, J.; Cossi, M.; Millam, J. M.; Klene, M.; Adamo, C.; 
Cammi, R.; Ochterski, J. W.; Martin, R. L.; Morokuma, K.; Farkas, O.; Foresman, J. B.; Fox, D. J. Gaussian 16, revision A.03; Gaussian, Inc.: Wallingford, CT, 2016.

(2) Sun, H.; Zhang, D.; Wang, F.; Liu, C. Theoretical study of the mechanism for the Markovnikov addition of imidazole to vinyl acetate catalyzed by the ionic liquid [bmIm] OH. J. Phys. Chem. A. 2007, 111, 4535-4541.

(3) Yang, D.; Chen, T.; Wang, Z.; Electrochemical reduction of aqueous nitrogen $\left(\mathrm{N}_{2}\right)$ at a low overpotential on (110)-oriented Mo nanofilm. J. Mater. Chem. 2017, 5 , 18967-18971.

(4) Yao, J.-X.; Bao, D.; Zhang, Q.; Shi, M-M.; Wang, Y.; Gao, R.; Yan, J.-M.; Jiang, Q. Tailoring Oxygen Vacancies of $\mathrm{BiVO}_{4}$ toward Highly Efficient Noble - Metal - Free Electrocatalyst for Artificial $\mathrm{N}_{2}$ Fixation under Ambient Conditions. Small Methods. 2018, 3, 1800333.

(5) Wang, J.; Yu, L.; Hu, L.; Chen, G.; Xin, H.; Feng, X. Ambient ammonia synthesis via palladium-catalyzed electrohydrogenation of dinitrogen at low overpotential. Nat. Commun. 2018, 9, 1795.

(6) Zhang, L.; Ji, X.; Ren, X.; Ma, Y.; Shi, X.; Tian, Z.; Asiri, A. M.; Chen, L.; Tang, B.; Sun, X. Electrochemical Ammonia Synthesis via Nitrogen Reduction Reaction on a $\mathrm{MoS}_{2}$ Catalyst: Theoretical and Experimental Studies. Adv. Mater. 2018, 30, 1800191.

(7) Nazemi, M.; El-Sayed, M. A. Electrochemical Synthesis of Ammonia from $\mathrm{N}_{2}$ and $\mathrm{H}_{2} \mathrm{O}$ under Ambient Conditions using Pore-Size-Controlled Hollow Gold Nanocatalysts with Tunable Plasmonic Properties. J. Phys. Chem. Lett. 2018, 9, 5160.

(8) Huang, L.; Wu, J.; Han, P.; Al-Enizi, A. M.; Almutairi, T. M.; Zhang, L.; Zheng, G. $\mathrm{NbO}_{2}$ Electrocatalyst Toward $32 \%$ Faradaic Efficiency for $\mathrm{N}_{2}$ Fixation. Small Methods, 2018, 1800386

(9) Wang, H.; Yu, H.; Wang, Z.; Li, Y.; Xu, Y.; Li, X.; Xue, H.; Wang, L. Electrochemical fabrication of porous $\mathrm{Au}$ film on $\mathrm{Ni}$ foam for nitrogen reduction to ammonia. Small. 2019, 15, 1804769.

(10) Bao, D.; Zhang, Q.; Meng, F.-L.; Zhong, H.-X.; Shi, M.-M.; Zhang, Y.; Yan, J.-M.; Jiang, Q.; Zhang, X.-B. Electrochemical Reduction of $\mathrm{N}_{2}$ under Ambient Conditions for Artificial $\mathrm{N}_{2}$ Fixation and Renewable Energy Storage using $\mathrm{N}_{2} / \mathrm{NH}_{3}$ Cycle. Adv. Mater. 2017, 29, 1604799.

(11) Kordali, V.; Kyriacou, G.; Lambrou, C. Electrochemical synthesis of ammonia at atmospheric pressure and low temperature in a solid polymer electrolyte cell. Chem. Commun. 2000, 1673-1674

(12) Shi, M.-M.; Bao, D.; Li, S.-J.; Wulan, B.-R.; Jiang, Q. Anchoring PdCu Amorphous Nanocluster on Graphene for Electrochemical Reduction of $\mathrm{N}_{2}$ to $\mathrm{NH}_{3}$ under Ambient Conditions in Aqueous Solution. Adv. Energy Mater. 2018, 8, 1800124.

(13) G. F. Chen, X. Cao, S. Wu, X. Zeng, L. X. Ding, M. Zhu, H. Wang, Ammonia electrosynthesis with high selectivity under ambient conditions via a $\mathrm{Li}+$ Incorporation strategy. J. Am. Chem. Soc. 2017, 139, 9771.

(14) Nazemi, M.; Panikkanvalappil, S. R.; El-Sayed, M.A. Enhancing the rate of electrochemical nitrogen reduction reaction for ammonia synthesis under ambient 
conditions using hollow gold nanocages. Nano Energy. 2018, 49, 316-323.

(15) Liu, Q.; Zhang, X.; Zhang, B.; Luo, Y.; Cui, G.; Xie, F.; Sun, X. Ambient N 2 fixation to $\mathrm{NH} 3$ electrocatalyzed by a spinel $\mathrm{Fe}_{3} \mathrm{O}_{4}$ nanorod. Nanoscale. 2018, 10, 14386-14389. 